QIJIS: Qudus International Journal of Islamic Studies

Volume 7, Number 2, 2019

DOI : $10.21043 /$ qijis.v7i2.4797

\title{
RECONSTRUCTION OF FIQH NUSANTARA: Developing the Ijtihad Methodology in Formulating Fiqh from Indonesian Perspective
}

\author{
Abdurrohman Kasdi \\ Institut Agama Islam Negeri (IAIN) Kudus, Indonesia \\ abdurrohmankasdi@iainkudus.ac.id
}

\begin{abstract}
Fiqh Nusantara which is relevant to Indonesian Muslims is Fiqh that is suitable for the personality and character of the Indonesian people so that it can meet their needs. The importance of taking Fiqh stipulations from the results of Ijtihad that is more in line with the needs of the Nusantara community makes Fiqh not rigid in applying it. Fiqh Nusantara exists to revive the Fiqh so that it can participate in shaping the directions and movements of Indonesian people's lives. This article aims at analyzing the reconstruction of Fiqh Nusantara, by developing the methodology of Ijtihad (Process of legal reasoning in rationalizing law based on the Qur'an and Sunnah) to formulate Fiqh (Islamic law) that is compatible with Indonesian people. The research used qualitative methods with juridicalsociological approaches. The result of this research shows that Fiqh Nusantara evolves along with the introduction of Islam in Indonesia which is known as Nusantara at that time. The reconstruction of the Fiqh Nusantara is done by reinterpreting the Shara theorem contained in traditional Fiqh, by reading the conditions of the community to realize the objectives of Islamic law, while referring to the Mazhab (school of thought) and Ijtihad as an effort to solve problems that occur in Indonesia by considering local wisdom, traditions, or customs.
\end{abstract}

Keywords: Reconstruction, fiqh nusantara, methodology of ijtihad. 


\section{A. Introduction}

Islam was not present in a vacuum world, but rather in communities with a certain historical, cultural and intellectual background. In this case, the universal Islamic teachings pay attention to the situation, conditions, and cultural specificities of the communities where Islam is revealed and taught. It is because each generation will change according to the different development. The rule of Usul al-Fiqh said that the law consideration changes according to the changing of place, time, place, custom, and condition (al-Hukmu Yataghayyar bi Taghayyur al-Azminah wa al-Amkinah wa al-Ahwal wa al'Adat). Therefore, it is reasonable that the relevance of Islam throughout the time lies in the values and norms created from the methodological provisions in the Fiqh rules.

The characteristic of Fiqh is dynamic, flexible, and not rigid in understanding the text, so that social orientation that is more humane especially in Islamic life in Indonesia can be practiced well. Therefore, it is urgent to formulate Fiqh as a result of Ijtihad that is compatible with the Indonesian peopless needs while providing solutions to new problems, especially in the aspect of Muamalah, which law provisions do not yet exist.

The existence of Fiqh Nusantara is vital in responding to religious life in Indonesia. This Fiqh is suitable and can satisfy the Indonesian people's needs. For example, the status of customs (urf) that develop among them which is not contradictory with Syara', beside of other questions that need to answer: How does Fiqh Nusantara respond to Pancasila as the singular principle of Indonesian country? How does Fiqh Nusantara establish rules regarding problems that are 
not established detailly in al-Qur'an and Sunnah? Is Fiqh Nusantara accommodative towards local wisdom that lives at the center of the social reality of Nusantara people itself? How does Fiqh Nusantara respond to environmental problems and natural resources in Indonesia that are exploited more and more by capitalists? All those questions are relevant to strengthen the existence of Fiqh Nusantara. Considering it, the urgency of the study about Fiqh Nusantara lies, especially when it is correlated to the spirit to develop Fiqh that is suitable to Indonesian people.

Studies on Islam Nusantara and Fiqh Nusantara have been conducted, among others, by JM. Muslimin, Law, and Culture: 'Urf as a Substance of Islam Nusantara as Reflected in Indonesian Religious Court Decisions, Atlantis Press (Muslimin, 2018). Likewise with a study conducted by Musawar and Muhammad Harfin Zuhdi, Islam Nusantara that is Sacred and Ignored (Thinking Analysis of Sasak Lombok Ulama), United States: Journal of Legal, Ethical and Regulatory Issues (Musawar \& Zuhdi, 2019). Moh. Mukri et.al. wrote about Constructing the Epistemological Aspect of Fiqh Nusantara, Journal of Academics (Mukri, Mustofa, \& Fauzan, 2019). Also, M. Nor Harisudin, The Taqnin of Indonesian Islamic Law Dynamic, Journal of Indonesian Islam (Harisudin, 2015). However, their studies are still general and normative, therefore the study of the reconstruction of the Fiqh Nusantara is important for formulating fiqh that can be applied in Indonesia.

The research of Fiqh Nusantara uses a qualitative method with the juridical-sociological approach (Sorokin, 1928: 760-761). The Sociology being used is Nusantara 
sociology, which studies the emergence, development, and social institutionalization of Nusantara people (Jurdi, 2013: 65-66). The research is conducted by reconstructing the Fiqh Nusantara study tradition alongside the cultural roots as its background. The study process is carried out systematically and objectively by collecting, evaluating, and testing evidence that supports the data and obtaining a strong conclusion through collecting data regarding the concept, opinion, attitude, and judgment towards the situation and understanding about Fiqh Nusantara.

The research offers a new perspective towards research study focus and exploration of the essence formed by life reality in the development of social sciences (Schutz, 1970: 30). The sources of data for this research are literature, documents about Fiqh Nusantara, and interviews of Fiqh Nusantara experts. The types of data consist of primary data and secondary data. Primary data is sourced from official documents, in-depth interview with prominent figures, and literature discussing Fiqh Nusantara. Interviews were conducted with several experts who were competent in the study of Fiqh Nusantara, including KH. M. Tholhah Hasan and KH. A. Mustofa Bisri. While the secondary data is sourced from magazines, journals, newspapers, and other related researches.

Fiqh Nusantara and Islam Nusantara are popular among Indonesian people (Kasdi, 2018: 313-316). Research on Fiqh Nusantara is a research field that can unmask the history of thought and life of the Indonesian nation (Johns, 1958: 5). If it is analyzed and linked to the development of the Islam Nusantara, it can be stated that the rituals carried out by the 
Indonesian people contain high cultural values. In turn, the religious practices they carried out reflected the religious patterns of the Fiqh Nusantara.

\section{B. From Normative Fiqh Towards Humanity Fiqh}

The word Fiqh etymologically means to understand the utterance of someone. Therefore, Fiqh means deep understanding (Fahm Daqiq) (Al-Khin \& Al-Bugha, 1996: 7). This word is found in al-Qur'an in 20 verses, but most relevant to the Islamic studies in Allah's word: "It is not advisable for the believers to march out altogether. Of every division that marches out, let a group remain behind, to gain an understanding of the religion, and to notify their people when they have returned to them, that they may beware." (QS. Al-Taubah:122)

This verse reminds us so that not all Muslims go to war (Al-Maraghi, 2006: 187-188), that there should be a group of people from each community that study and understand (li Yatafaqqahu) religious teachings (Shihab, 2005: 749-752). The object of Fiqh includes various broad issues, ranging from utterance (QS. Taha: 28), occurrence and the punishment of hell (QS. Al-Taubah:81), Tasbih (QS. Al-Isra': 44), the verses of God (QS. Al-An'am: 65,98), the change of heart (QS. Al-Taubah: 127), hypocrisy (QS. Al-Mukminun: 7), to religious issues (QS. Al-Taubah: 122).

Meanwhile, terminologically, Fiqh is the science that explains practical Islamic law based on the detailed source from Qur'an and Sunnah (Al-Zuhaili, 1997: 29-30). Therefore, Fiqh is a science created by thought, research, and Ijtihad which requires thinking and contemplation (Schacht, 2010: 74-75). In its development, the word Fiqh usually defined as 
the establishment and provision related to the action of a law subject (Mukallaf) which comes from or based on the Divine guidance (Khithab) (QS. Al-Nisa': 105).

The purpose of establishing Fiqh is realizing the wellbeing of mankind in the world and the hereafter (Al-Syatibi, 2003: 30), through applying Shari'a law into peoples' actions and utterances, and guiding them in worship and transaction. Furthermore, the function of Fiqh is to summarize many theorems, search their authenticity and examine their legal process (Istidlal), and also combine one theorem with another into a law conclusion. Then, these laws are compiled into chapters that make it easily referenced (Shahrur, 2004: 164-170).

Fiqh is the expression of the laws that Allah established towards His servants, to protect their well-being and prevent harm among them. Therefore, fiqh exists to give attention to those aspects and to regulate all actions. The issues of Fiqh occupy the largest portion of Islamic studies. The term ulama is more often identified to Fiqh expert rather than other disciplines experts. It is because a Fiqh expert must also be an expert in Tafsir, Hadith, Linguistics, Usul al-Fiqh, and others (Sholeh, 2016: 126-128).

Fiqh, which means Islamic laws regulate the actions of Mukallaf, has a connection with the belief in Allah and other commandments of Islamic faith because it will allow a Muslim to stay true towards religious laws, and follow them as the embodiment of obedience and compliance. Meanwhile, people who don't believe in Allah do not feel obliged to perform religious commandments such as praying or fasting and do not give attention to whether their action is Halal or Haram. 
Hence, staying true to Islamic law is part of the Muslim's faith towards Allah Who has revealed and commanded it to mankind (Schacht, 2010: 21-26).

Therefore, Fiqh is the values of Islamic teachings with the normative dimension as the basic rule for a Muslim in performing their religious teachings. This rule emerges and develops along with the practice of Islam itself. When Islam was practiced during Rasulullah and his Companions' era, the rules for how to practice Islam developed. It was also happened in the Tabi'in era and afterward (Shahrur, 2004: 164-178).

At the beginning of Islam, Fiqh is actualized in empirical reality, not yet become a discipline (An-Na'im, 2004: 2326). Fiqh as Islamic teaching was practiced based on the understanding at the time, which was normative and practical, suitable with people's needs. With this kind of practice, it's unsurprising that Fiqh corresponded to the condition where Arab people and their culture practiced Islam. Moreover, the practice of Islam at that time put more importance towards implanting Aqeeda and awareness to practice Islamic teaching, rather than the formal dimensions of Fiqh.

For example, it was advised in Thaharah (purity) to use Siwak in performing worship. Rasulullah said, "If it were not that it would be difficult on my people, then I would have ordered them to use the Siwak for each prayer." The understanding of this hadith is a suggestion for any Muslim to use Siwak before worshiping. The practice of Siwak as a mean of purification and the ritual of worship merged into one single activity. (Mahfudz, 2017). 
However, understanding Siwak as a necessity to obtain Sunnah in worship is tempting to our mind because the mean of purification is not only Siwak but can also be toothpaste or other hygiene product. If fanatism and formality in performing worship are understood rigidly, then using anything other than Siwak means not getting the sunnah of purification explained in the hadith above.

Therefore, the study of Fiqh Nusantara should be appreciated as a review of the ever-evolving practice of Islamic teachings. The development of Fiqh Nusantara requires ideas from Muslim experts, empirical experience from the practice of Islamic teachings in Indonesia which can be emulated in other parts of the Islamic world because the Indonesian Muslim has the largest population in the world (Bizawie, 2016a: 239-240).

\section{Genealogy of Fiqh Nusantara}

Fiqh Nusantara emerges together with the introduction of Islam into Nusantara soil, starting from the Walisongo era, colonialism, post-independence revival, the new order with the rapid modernization, until today's modern era. In all these phases or periods of the development of Islam in Indonesia, it seems that Islamic teachings can always be practiced by its believers in Indonesia. The choice of Fiqh that was being taught at the time was also moderate Fiqh which can get along well with the Nusantara culture (Wahid, 2016: 36-37).

Walisongo and the ulama spreading Islamic teachings in Indonesia introduced Islam with the cultural approach so that Islam can be easily understood and practiced without abandoning the principles of Islamic teachings. (Kasdi, 2017: 
15-16). The historians see this tactic as an accommodative strategy, which is the wisdom of Islamic missionaries in dealing with acculturation processes. The success of Walisongo is because of their Da'wa strategy that reaches all parts of Java, and even the whole of Nusantara (Kasdi, Farida, \& Cahyadi, 2019: 468). The introduction of Islam to the people through the dialogue forums, sermons, art and cultural performance, that had no element of coercion.

In the colonialism era, the implementation of Islamic law (Fiqh) in Indonesia also faced the problem from the colonial ruler at the time so that conducting the compromise towards Recepcie policy by the Dutch government, and Fiqh could apply as long as it did not conflict with the customary law. Beside it, they can also hold the reverse theory, "Recepcie in Contrario" that the customary law and Fiqh practice can be applied alongside each other for Nusantara people. After they achieve independence and Islamic teaching increasingly widespread in Indonesia, they began to require Fiqh that was compatible with them.

Hasbi ash-Shiddieqy was the person who first revealed the idea of Indonesian Fiqh (Ma'arif, 2015: 28-30). He dubbed the Fiqh with special characteristics of Indonesian people as Indonesian Fiqh. According to him, Fiqh with Indonesian personality must exist. This Idea was triggered by the stagnation of Fiqh in 1940 that couldn't give a solution to people's problems. In his first article titled Memoedahkan Pengertian Islam, he stated the importance of establishing fiqh as the result of ijtihad that is compatible with Indonesian people's need, so that Fiqh is not seen as a foreign object and treated like an antique. 
Shiddieqy was doubtful of the prospect and the future of Islamic law in Indonesia which had no clear direction. He saw the significance to review the Indonesian people's attitude who cult of existing Islamic laws based on putting new Ijtihad systems, aside from the need for formulating new legal alternatives for the concepts and ideas of Islamic laws that considered irrelevant to be practiced in Indonesia.

For a long time, up until 1948 to be exact, his Indonesian Fiqh idea did not receive a positive response. Then, he wrote another article titled Menghidupkan Hukum Islam Dalam Masyarakat published in Aliran Islam magazine. (Shiddiqi, 1997: 215-216). He attempted to revive his big idea. In his article, he stated that the Islamic law's existence in practice has reached a clinical level of decadence, and appeared as the outcast figure, insignificant, and useless. Its presence is no longer recognized by people because it was no longer able to accommodate the demand for modernity (Fuad, 2016: 205).

According to Shiddieqy, Islamic law has to solve human's new problems, especially in the aspects of Muamalah, there are still problems with no legal provisions (Rahmiyati, 2017: 165). It must be able to be present and to participate in shaping the direction of people's life. One of the factors causing ulama in this country to be incapable of establishing Fiqh with Indonesian personality is their excessive fanaticism towards the Mazhab followed by Muslims. Realizing the impossibility of the emergence of the progressive idea from conservative ulama, he invited Indonesian Islamic College circles to create a new generation of mujtahid with special characteristics that can carry on Indonesian Fiqh project. 
In 1961, Shiddieqy reiterated his Indonesian Fiqh idea in the IAIN Sunan Kalijaga anniversary event. In the scientific speech themed, Syariat Islam Menjawab Tantangan Zaman (Islamic Shari'a Answering the Challenges of the Age), he asserted that Indonesian Fiqh is Fiqh that is established following Indonesia's personality, and compatible with the nature and characteristics of Indonesia (Ash-Shiddieqy, 1966). After this scientific speech, his idea finally received a positive response from the Indonesian people. Shiddieqy presented the Indonesian Fiqh idea with his bravery, which was seen as taboo at the time. The influence of Shiddieqy's idea was incredible. Islamic law began to have an honorable place. Previously, in the national law system, Islamic law was placed as a part of the customary law, but after the disclosure of Shiddieqy's idea, Islamic law became an independent element of the national law.

There are four steps offered by Hasbi ash-Shiddieqy in approaching towards Indonesian Fiqh. They are: first, recompiling old Fiqh books in a form and system that is compatible with the advance and demand of modernity. Second, compiling Fiqh book as a guideline for reviewer or Islamic law researcher, which contains descriptions of the law based on an interpretation of al-Qur'an and supported by Hadith. Third, discussing law incidents that arise at present and is related to the life and movement of Indonesian people, such as the issue of riba in the bank, gambling, etc. Fourth, conducting a comparative study between Islamic law and conventional positive law (Shiddiqi, 1997: 229).

An example of Shiddieqy's Indonesian fiqh idea is when he stated it's necessary to review the definition of wealthy to be adjusted to today's standard so that those who are required 
to pay zakat do meet the requirements to be categorized as wealthy. In Shiddieqy's view on the limit of zakat's Nisab, he wanted the exact value of 20 Mithqal in today's standard to be reviewed. It is because this standard is the standard for categorizing a person as wealthy. Notwithstanding Shiddieqy himself admit that the value is equal to 96 grams of gold, he also questioned the accuracy of this calculation when adjusted to today's situation and condition.

Shiddieqy saw if in the Prophet's era 20 Mithqal can buy a person five camels, is it also applied today? It can be seen that Shiddieqy wanted an additional analytical tool to establish the measurement of wealth categorization which has the law consequence of someone having to pay Zakat. This additional analysis can be in the form of modern science, like economics and local culture, so that the establishment of the amount of Zakat is more suitable for today's standard.

The Indonesian Fiqh idea presented by Hasbi ashShiddieqy was further developed by Hazairin. As well as Shiddieqy, Hazairin expressed the need to form national Mazhab fiqh for Indonesian Muslims. This Mazhab has undergone several considerations, which he then called fiqh Mazhab Indonesia (Hazairin, 1982: 5-6). The emergence of the national Mazhab Fiqh idea, among others, was triggered by the Dutch colony who eliminated the development of the legislation of Islamic law in Indonesia. Through the idea that was packaged in the concept of Het Indiche Adatrecht with its intellectual figures such as van Vollenhoven (1874-1933) and Snouck Hurgronje (1857-1936), that was later known as Receptie theory (Fuad, 2016: 10), the Dutch government attempted to constrict the application of Islamic law. 
As the counter-theory, Hazairin constructed the Receptie Exit theory. This theory stated that the Receptie theory must exit from the Indonesian Islamic law theory because it's contradictory to the UUD 1945 and al-Qur'an and hadith (Hazairin, 1976: 7-8). Through this theory, Hazairin tried to prove that customs (anthropology) do not always conflict with Islam. He also systematized the national law with three elements, including the Dutch law, customary law, and Islamic law.

According to Hazairin, Syara' sources and the law found in traditional Fiqh need to be reinterpreted, by reading the condition of the local society so that the goal of Islam can be reached, by using the sociocultural historical approach. (Fuad, 2016: 83).

The effort to be constructive Ijtihad from various provisions of Islamic law are always faced with certain conditions and situations so that the nuances of engineering and sublimation will always appear in it. Accordingly, as revealed by Joachim Wach quoted by Mahsun Fuad, religious experiences and thoughts that cannot be separated from the context, both the context of the time, space context, historical context, social context, cultural context, psychological context, and religious context (Fuad, 2016: 15-16).

The focus of the Hazairin study is an inheritance, so the operationalization of this interpretation pattern can be taken by gathering all the verses and hadiths that are related to inheritance, then interpreting them as a unity that explains each other. In explaining the understanding and concepts in that verse, Hazairin suggested the need to use an anthropological frame of reference. 
The Genealogy of the Fiqh Nusantara was followed by the social Fiqh idea of KH. Sahal Mahfudh. This discourse of social Fiqh started when many problems arise in classical Fiqh. He tried to respond to criticism by advocating for classical Fiqh. This step then continued by a systematic effort with the publication of the Nuansa Fiqh Sosial book (Mahfudh, 1994: 3-17). According to him, the current Fiqh is sufficient, but there are still troubles in its presentation and reformation. So, it's needed to reconstruct Fiqh, then to publish it in people's lives.

Mahfudh emphasized that the five basic principles of humanity formulated by al-Syatibi in Maqashid al-Shari'a, it means that to provide an understanding to the public that Islam does not specialize in its role only in the matter of Ta'abbudi (worship of Allah), it is command and prohibition only. If the problem is not purely in the area of interaction between servants and God, then the values of benefits are recommended to be considered. Here, the Fiqh Nusantara that is social-oriented was developed with an emphasis on social orientation in the context of Islamic law to realize human well-being and prosperity.

Then, some ulama and thinkers in Indonesia have also a contribution to building the Fiqh Nusantara, including the social fiqh thought by $\mathrm{KH}$. Ali Yafie, the indigenous efforts of Islam by KH. Abdurahman Wahid (Wahid, 2016: 33), the reformation of Mazhab by Qadri Azizi and others to continue the ulama of Islam Nusantara to carry out Fiqh according to the Nusantara community conditions (Azizy, 2003: 84).

In the Reformation era, Islamic law became Qanun (positive law) in this country such as the Constitution No. 1 of 
1971 concerning Marriage, Compilation of Islamic Law (1991), the Constitution concerning zakat (1999 revised 2011), the Constitution No. 4 of 2004 concerning Endowments, the Constitution of Shari'a Banking (2008) and others. It shows that the efforts of Indonesian Muslim thinkers to socialize Islam and Islamic law in the frame of the Nusantara society always dynamic moving to realize the religious teaching forms, based on Islam and Nusantara aspects since there is synergy between the two that is equally applicable in Indonesia.

\section{Methodological Transformation of Fiqh Nusantara}

Realizing the Fiqh Nusantara need a high level of awareness and wise from several parties. Moreover, in carrying out historical reflections and methodological transformations of Islamic law thinking in the early development era. Considering the local traditions as a reference for the forming of a new Islamic law thinking is urgent (Saputra, 2018: 182183). The Islamic Shari'a is based on the principle of equality by involving all customs ('Urf)of each society can be used as reference law, not only the customs of Arab society but also 'Urf of the people of Nusantara. Fiqh Nusantara that is applied to Indonesian Muslims, it is suitable Fiqh for them, namely the 'Urf that develops in Indonesian society, which is not contrary to Syara' (Ghazali, 2016: 112-114).

Fiqh Nusantara can be accounted for methodologically because it based on at least three main theorems: Istihsan, Maslahah Mursalah, and 'Urf. Istihsan is the consideration the good deeds is that what is considered good by the majority of Muslims (Al-Fasi, 2011: 251). Maslahah Mursalah is a Maslahah that is not commanded or prohibited directly by Syara', but contains dimensions of real and general benefits 
(Al-Zuhaili, 1996: 753-754). Whereas 'Urf is a tradition applied in the community (Al-Zuhaili, 1996: 828). These three theorems strengthen the epistemological basis of the Indonesian Fiqh.

In Usul al-Fiqh, there is the concept of 'Urf, local wisdom, or customs which is one of the theories in Fiqh methodology that makes customs (as long as they do not contradict with the Shari'a principles) as one of the considerations in deciding the Fiqh law. This consideration results in the rules of Fiqh: al-'Adatu Muhakkamah (customs can be a reference law) (Al-Suyuti, 1998: 193-194). Here, Abdurrahman Wahid emphasized that religious symbolism had been allowed in the culture, so that Islam was able to actualize the main ideals, namely: democracy (Shura), justice ('Adalah), and equality (Musawah) (Wahid, 2001: 111-112).

Besides, there is also the rule of al-Hukmu Yataghayyar bi Taghayyur al-Azminah wa al-Amkinah wa al-Ahwal wa al'Adat (law consideration changes according to the change in time, place, condition, and customs) (Al-Qayyim, n.d.: 3). So, it is no exaggeration if the ulama keeps Islam relevant throughout the time (Salihun li Kulli Zaman wa Makan), is the values and norms created from the aforementioned fiqh methodology.

The majority of Fiqh adhere to Ijtihad Qauli, namely the effort to find the law based directly on the opinions of the ulama, especially in the Syafi'i Mazhab. This Ijtihad shows that the Syafi'i Mazhab has a status quo progressively in the Fiqh Nusantara. Finally, the Syafi'i Mazhab in Fiqh became the standard characteristic of Islam Nusantara (Bizawie, 2016b: 4-5). Whereas, in the Usuliyyin debates, this Ijtihad Qauli 
still has several problems, especially in the present days. The classical Fiqh as the reference was born based on the need of medieval society in a certain region and cultural contexts, while people live in another region with different cultural contexts. So, some of its law results are a reflection of each region and the period.

There has been a methodological transformation of Fiqh in the Islam Nusantara. Bahtsul Masail and law discussions are not only always based on the nash of Fuqaha contained in authoritative books (al-Kutub al-Mu'tabarah), but also the Nusantara ulama are also doing ijtihad collectively (Ijtihad Jama'i) using a set of four methods of Mazhab (Muhammad, 2002: 26-35). The collective Ijtihad is like an Islamic law institution in which there are experts from various disciplines. The laws decided through intensive and neutral research, not influenced by the government or certain groups (AshShiddieqy, 1973: 17).

In addition, there has been a transformation in the textual Mazhab process towards the methodological Mazhab process. It means implementing Ijtihad based on methodology that have been decided in the Mazhab (Al-Khin \& Al-Bugha, 1996: 15). Through this methodological process, Fiqh become more adaptive to Indonesian local wisdom and tradition. (Mahfudh, 1994: 40-49). Thus, the kind of Mazhab or Ijtihad necessitates an effort to solve the problems that occur in Indonesia by considering local wisdom, traditions, or customs. It is because the methodology used in formulating Fiqh Nusantara is the fourth school of law methodology (Mazhab) which is sociologically very adaptive to the cultural factors as one of the local considerations of law. 
Ijtihad is carried out to reconstruct the Fiqh Nusantara, by paying attention to the following: First, interpreting the Zhanni texts by flexible ways because the verses of the Qur'an has two versions: in the form of Muhkamat (verses that contain clear meanings) and Mutasyabihat (verses that contain vague meaning). The verses of the Qur'an, ulama has the discretion to interpret them, especially those that are often related to the reality of society. Therefore, the results of each ulama are different from one another.

Second, reinterpreting heritage of Islamic jurisprudence (Turats al-Fiqh). By interpreting and reviewing the heritage of old Ulama, we will be able to solve the national problems and the people without being interfered with the intellectual roots that have been passed down through generations. The new interpretation takes into account the socio-cultural that is in the local community.

Third, considering the 'Urf (culture, customs, and traditions) as part of the creations produced by the community (Ghazali, 2016: 112). Even Imam Syatibi put 'Urf in a strategic position as a reference for Islamic law (Al-Syatibi, 2003: 12). But the 'Urf that used is 'Urf Shahih (good), because 'Urf is divided into two, namely are 'Urf Shahih (good) and 'Urf Fasid (bad). For the second, it can not be used as a law reference, notwithstanding most people are to do it. For example, some Indonesians do KKN (Corruption, Collusion, and Nepotism), but this habit cannot be used as a law decision, because it is a bad habit.

Fourth, considering the universal and absolute benefits that have been determined by Nash. The relevance of this universal benefit will interact with al-Kulliyat al-Khamsah 
or what is often called to as Maqashid Shari'a, including guarding religion (Hifz al-Din), guarding the soul (Hifz al$N a f s$ ), guarding reason (Hifz al-Aql), guarding offspring (Hifz al-Nasl) and guarding the property (Hifz al-Mal) (Al-Syatibi, 2003: 30-32).

According to Ibrahim Hosen, The chair of the Fatwa Commission of Indonesian Ulama Council (MUI), renewal of religious thought in Indonesia can be done in several ways: First, abandoning the literal understanding of the Qur'an and replacing it with an understanding based on the spirit and soul of the Qur'an. Second, taking the soul of Sunnah of the Prophet PBUH for legislation provisions and provide discretion to develop the techniques and implementation of worldly problems. Third, changing the devotional (Ta'abbudi) approach in reading the texts towards the prudential ( $\mathrm{Ta}^{\prime}$ 'aqquli) approach. Fourth, breaking away from the old style of determining the pathways to root causes of problems (Masalik al-'Illah) and developing the formulation of the root of problems for the new law. Fifth, shifting the attention from the criminal problem set by text to the criminal offense and the most democratic matters. Sixth, supporting the government to generally text and limit it (Hosen, 1989).

Nevertheless, the transformation of Mazhab from textual to the methodological pattern is an effort to contextualize Islamic teachings in social conditions in some places and times. The methodology used still characterizes the Islam Nusantara, one of which in Fiqh follows the Syafi'i Mazhab or more generally follows the four Mazhabs (Mazahib al-Arba'ah) with contextual understanding. This 
consideration is important because with the transformation of this methodology, the effort to create Fiqh that is more reality of Nusantara that confirms the characteristics of the Islam Nusantara that has known internationally.

\section{E. Fiqh Nusantara as the Indonesian Perspective Fiqh}

Fiqh Nusantara is Fiqh practiced according to the reality in Indonesia which is also known as Nusantara. The reasoning thinking used in the ideas of Fiqh Nusantara is a belief that the principles of the Islamic law provide a space for new development and ijtihad. The principles of Islamic law that have been used (Al-Qayyim, n.d.: 3) such as Ijma', Qiyas, Maslahah Mursalah, 'Urf and the principle of change law because of time and place, it will get discrepancies when there is no new Ijtihad. Based on this paradigm, the movement to close the Ijtihad is an old issue that must be ignored immediately in the context of the present-day. (AshShiddieqy, 1966: 42).

The Fiqh Nusantara thought also use the principle of Maslahah Mursalah, justice, expediency, and Sadd adzDzari'ah (Ash-Shiddieqy, 1975: 186-187). All of these are combined principles held by the Mazhab priests, especially the Madinah and Kuffah form which have proven capable to create the order and prosperity in society. In realizing the Fiqh Nusantara, a critical historical approach is significant. The deductive analogy method, for instance, as a model of Istinbath used by Abu Hanifah and the inductive analogy method used by Imam Shafi'i, to discuss one problem that has not been found a law provisions in the scope of Fiqh thought. 
Therefore, the problems that have already had law provisions, the comparison method is an important thing to do. Consequently, it is necessary to compare one opinion with another opinion from all of the law references or that have existed, choose which ones are more suitable and closer to the truth, and supported with strong arguments (Al-Zuhaili, 1996: 197-199). Fiqh Nusantara uses a socio-culturalhistorical approach to facilitate the application method in all processes of the study and discovery of Islamic law.

Nevertheless, Fiqh Nusantara has two forms: living laws and positive laws. Both are a part and wealth of the Nusantara Islamic jurisprudence (Harisudin, 2015: 89-90). As living laws, we can see Fiqh Nusantara in the discussion books at Islamic Boarding Schools, Issues Research Committee of Nahdlatul Ulama, Muhammadiyah Tarjih Council, Hisbah Commission of PERSIS (Islamic Unity Organization), Fatwa of MUI and so on, all of which become the reference of a fatwa for people. Nevertheless, as positive law, we see Fiqh Nusantara standardized in regulations that are set by the government for all Muslims. In the positive law, the rule applies that the legal decisions taken by the leader or judge are absolute and fair (Hukmu al-Hakim Yulzimu wa Yarfa' al-Khilaf).

Another result of Fiqh Nusantara which has been decided as regulation in the Compilation of Islamic Law (Kompilasi Hukum Islam/KHI) is the property of Gonogini. Gono-gini is the property acquired jointly of husband and wife after marriage. In KHI, it is mentioned that the inheritance will be divided after the property of the Gonogini, the husband and wife are divided together (Mokodompit, 2015: 169-171). For example, if a husband dies and has 100 
million, then the money is divided for the wife of 50 million and 50 million for the husband. This 50 million, owned by the husband, is shared with the heirs. The Fiqh Nusantara model concerning Gono-gini property is better than the conventional Fiqh that practices in many Islamic countries, especially the Middle East.

Some events such as wedding reception, Syawalan, Kupatan, circumcision (Khitan), Slametan, Syukuran and so on have combined the Islamic teachings with the local traditions of Indonesian people (Bisri, 2018). In these events, the nuances of Fiqh Nusantara are obvious and dominant. It means that the cultural values or customs of the Nusantara community collaborate with Islamic values. There are synergies between Fiqh and the traditional customs of the Nusantara in several things: first, between fiqh and Nusantara, they both embody struggle to believe in Allah. The potential of monotheism (Tauhidiyah-Ilahiyah) in the religious tradition can develop in the Nusantara. Moreover, people also support to practice and believe there is something beyond human ability.

Second, Fiqh that developed in Indonesia always be able to adapt in its environment, so that it's implemented into a flexible, friendly, to every people, whereas the previous scholars fought for the actualization of Islam without armed with social sciences such as sociology, anthropology, politics, science, and technology. The flexible and accommodative concept of Fiqh with the peoples' reality was applied by the Nusantara scholars before (Hasan, 2017).

Third, the Fiqh Nusantara can develop based on the intention of sincerity to struggle for Islam. They did not think 
about their either to get social status, position, or personal interests. It can be proven by Fiqh which is the curriculum in the Islamic boarding schools as the embryo of the development of Fiqh in the Nusantara. The Islamic boarding schools in the early of the Indonesia establishment always took a place far from the crowds. The aims are Islam or Fiqh can be studied and practiced totally (Mahfudz, 2017).

In the third aspect, there is sincerity, cleanliness, and submission of the soul in Fiqh delivered by the Nusantara Ulama. Fiqh is not just normative teaching that is rigid, which seems to contradict with others. So the dimensions of the Fiqh Nusantara with the Sufism concurrently. For example, the followers of Sufism in Nusantara are mostly Ghazalian, those who followed the teachings of al-Ghazali in uniting the dimensions of Fiqh and Sufism.

\section{F. Conclusion}

The religious experience and thoughts that occur cannot be separated from the context that surrounds it, be it the context of the time, space context, historical context, social context, cultural context, psychological context, and religious context. Indonesian Muslim scholars to socialize Islamic law in the form of the Nusantara society are always dynamic moving, realizing the teaching forms based on Islam and Nusantara aspects. There are synergies between Fiqh and the traditional customs of the Nusantara in several things: first, between Fiqh and Nusantara, they both embody struggle to believe in Allah. Second, Fiqh that developed in Indonesia always be able to adapt in its environment, so that it can be implemented into a flexible, friendly, to other people. Third, 
the Fiqh Nusantara can develop based on the intention of sincerity to struggle for Islam.

The methodology in developing Fiqh Nusantara is reinterpreting the Syara' theorems contained in traditional Fiqh, by reading the local community conditions so that the purpose of Islamic law can be realized. Moreover, carrying out transformation in the practice of the process of the textual Mazhab towards the process of the methodological Mazhab. Referring to the methodological Mazhab is an effort to form a Fiqh Nusantara so that Fiqh is more adaptive to the local Nusantara wisdom and suitable with the benefit (Maslahat) of Indonesian Muslims. Nevertheless, referring to Mazhab and ijtihad are efforts to solve the problems that occur in the Nusantara by considering local wisdom, traditions, or customs. Because the methodology used is the Fiqh methodology of four Mazhab, sociologically it is very adaptive to cultural elements as one of the local considerations of law.

\section{REFERENCES}

Al-Fasi, 'Allal. (2011). Maqashid al-Syari'ah al-Islamiyyah wa Makarimuha. Cairo: Dar al-Salam.

Al-Khin, M., \& Al-Bugha, M. (1996). Al-Fiqh al-Manhajiy 'ala Madzhab al-Imam al-Syafi'i. Damaskus: Dal al-Qalam.

Al-Maraghi, A. M. (2006). Tafsir Al-Maraghi. Beirut: Dar alKutub al-'Ilmiyyah.

Al-Qayyim, I. (1997). I'lam al-Muwaqqi'in 'an Rabb al-'Alamin. Beirut: Dar al-Jayl.

Al-Suyuti, J. A. bin A. B. (1998). Al-Asybah wa al-Nadzair fi Qawaid wa Furu' Fiqh asl-Syafi'i. Beirut: Dar al-Kutub al'Ilmiyyah. 
Al-Syatibi, A. I. (2003). Al-Muwāfaqāt fì Ushul al-Syarī'ah. Cairo: Dar al-Taufiqiyyah.

Al-Zuhaili, W. (1996). Ushul al-Fiqh al-Islamiy. Beirut: Dar alFikr.

Al-Zuhaili, W. (1997). Al-Fiqh al-Islami wa Adillatuh. Beirut: Dar al-Fikr.

An-Na'im, A. A. (2004). Dekonstruksi Syariah (IV). Jogjakarta: LKiS.

Ash-Shiddieqy, H. (1966). Syariat Islam Menjawab Tantangan Zaman. Jakarta: Bulan Bintang.

Ash-Shiddieqy, H. (1973). Tugas Para Ulama Sekarang dalam Memelihara dan Mengembangkan al-Qur'ân Hadits dan Fiqh dalam Generasi yang Sedang Berkembang. Panji Masyarakat, XIV(123).

Ash-Shiddieqy, H. (1975). Falsafah Hukum Islam. Jakarta: Bulan Bintang.

Azizy, A. Q. (2003). Reformasi Bermadzhab: Sebuah Ikhtiar Menuju Ijtihad Saintifik-Modern (II). Jakarta: Teraju.

Bisri, K. A. M. (2018). Interview about the implementation of Fiqh Nusantara in everyday life. at Pesantren Raudlatut Thalibin secretariat office, Rembang, Central Java.

Bizawie, Z. M. (2016a). Islam Nusantara Sebagai Subjek dalam Islamic Studies: Lintas Diskursus dan Metodologis. In Islam Nusantara; dari Ushul Fiqih hingga Paham Kebangsaan. Bandung: Mizan.

Bizawie, Z. M. (2016b). Masterpiece Islam Nusantara; Sanad dan Jejaring Ulama-Santri 1830-1945. Jakarta: Pustaka Compass.

Fuad, M. (2016). Hukum Islam Indonesia: dari Nalar Partisipatoris Hingga Emansipatoris. In A. Salah \& M. 
Aziz (Eds.), Islam Nusantara, dari Ushul Fiqh Hingga Paham Kebangsaan (III). Bandung: Mizan.

Ghazali, A. M. (2016). Metodologi Islam Nusantara. In Islam Nusantara; dari Ushul Fiqih hingga Paham Kebangsaan. Bandung: Mizan.

Harisudin, M. N. (2015). The Taqnin of Indonesian Islamic Law Dynamic. Journal of Indonesian Islam (JIIS), 9(1), 79-100. Retrieved from https://doi.org/10.15642/ JIIS.2015.9.1.

Hasan, K. M. T. (2017). Interview about the dynamics of Fiqh Nusantara in Indonesian society. at his house, Singosari, Malang.

Hazairin. (1976). Hendak Kemana Hukum Islam. Jakarta: Tintamas.

Hazairin. (1982). Hukum Kekeluargaan Nasional. Jakarta: Tintamas.

Hosen, I. (1989). Sampai di Mana Ijtihad dapat Berperan. Bandung.

Johns, A. (1958). Mistik Islam dan Penulisan Sejarah di Indonesia. Jogjakarta: Islamic Study Club.

Jurdi, S. (2013). Sosiologi Nusantara: Memahami Sosiologi Integralistik. Jakarta: Kencana Prenadamedia Group.

Kasdi, A. (2017). The Role of Walisongo in Developing Islam Nusantara Civilization. Jurnal Addin, 11(1), 1-26. https://doi.org/10.21043/addin.v11i1.1973.

Kasdi, A. (2018). Islamic Dialectics and Culture in Establishing Islam Nusantara Paradigm (Variety Model of Islam Nusantara for Indonesia). Jurnal Addin, 12(2), 299-324. https://doi.org/10.21043/addin.v12i2.4537.

Kasdi, A., Farida, U., \& Cahyadi, I. F. (2019). Wali City Branding: Marketing Strategy in Promoting Halal 
Tourism Destinations Demak Indonesia. GeoJournal of Tourism and Geosites, 25(2), 463-473. https://doi. org/10.30892/gtg.25215-373.

Ma'arif, T. (2015). Fiqih Indonesia Menurut Pemikiran Hasbi ash-Shiddiqi, Hazairin dan Munawir Syadzali. Jurnal Pengembangan Masyarakat Islam, 8(2).

Mahfudh, M. S. (1994). Nuansa Fiqih Sosial. (H. Salim \& N. Amin, Eds.). Yogyakarta: LKiS.

Mahfudz, A. (2017). Fiqih Madzhab Nusantara. Retrieved January 2, 2019, from http://www.nu.or.id/post/ $\mathrm{read} / 62214 /$ fiqih-madzhab-nusantara

Mokodompit, Z. (2015). Penerapan Hukum Positif terhadap Harta Gono-Gini Dihubungkan dengan Hukum Islam. Lex Administratum, III(7), 16-23.

Muhammad, H. (2002). Tradisi Istinbath Hukum NU: Sebuah Kritik. In M. I. Rahmat (Ed.), Kritik Nalar Fiqih NU: Transformasi Paradigma Bahtsul Masai'l. Jakarta: PP Lakpesdam NU.

Mukri, M., Mustofa, I., \& Fauzan. (2019). Constructing The Epistemological Aspect Fiqh Nusantara. Akademika, 24(01), 135-149.

Musawar, \& Zuhdi, M. H. (2019). Islam Nusantara that is Sacred and Ignored (Thinking Analysis of Sasak Lombok Ulama). Journal of Legal, Ethical and Regulatory Issues, 22(3), 1-5.

Muslimin, J. (2018). Law and Culture: ' Urf as a Substance of Islam Nusantara as Reflected in Indonesian Religious Court Decisions. Atlantis Press, 154(1), 153-156.

Rahmiyati, R. (2017). Telaah Kritis terhadap Pemikiran Hukum Islam T.M.Hasbi As-Shiddiqie. Jurnal Petita, 2(November), 154-169. 
Saputra, E. (2018). Kawin Maupah: An Obligation to Get Married After Talak Tiga in The Tradition of Binjai Village in Pasaman District A Maqâshid al-Sharîah Review. Qudus International Journal of Islamic Studies (QIJIS), 6(2), 182-220.

Schacht, J. (2010). Pengantar Hukum Islam. Bandung: Penerbit Nuansa.

Schutz, A. (1970). On Phenomenology and Sosial Relations. Chicago: The University of Chicago Press.

Shahrur, M. (2004). Metodologi Fiqih Islam Kontemporer. Yogyakarta: Penerbit El-Saq Press.

Shiddiqi, N. (1997). Fiqih Indonesia; Penggagas dan Gagasannya. Jogjakarta: Pustaka Pelajar.

Shihab, M. Q. (2005). Tafsir Al-Misbah: Pesan, Kesan dan Keserasian Al-Qur'an. Jakarta: Penerbit Lentera Hati.

Sholeh, M. A. N. (2016). Metodologi Penetapan Fatwa Majelis Ulama Indonesia. Jakarta: Penerbit Erlangga.

Sorokin, P. (1928). Contemporary Sociological Theories. New York: Harper and Row.

Wahid, A. (2001). Pergulatan Negara, Agama, dan Kebudayaan. Jakarta: Desantara.

Wahid, A. (2016). Pribumisasi Islam. In A. Sahal \& M. Aziz (Eds.), Islam Nusantara, dari Ushul Fiqh Hingga Paham Kebangsaan (III). Bandung: Mizan. 